\title{
МЕТОДИЧНИЙ ПІДХІД ДО КІЛЬКІСНОГО ОЦІНЮВАННЯ СПРОМОЖНОСТЕЙ МЕДИЧНИХ ПІДРОЗДІЛІВ ЗБРОЙНИХ СИЛ УКРАЇНИ
}

\author{
€.0. Зуй \\ Українська військово-медична академія, м. Київ, Україна
}

Вступ. У статті запропоновано методичний підхід до модульного кількісного оцінювання спроможностей медичних підрозділів Збройних Сил України, в основу якого покладено модульний підхід до побудови та оцінювання медичних підрозділів, що застосовується у Північноатлантичному Альянсі. Аналіз затверджених методів оцінювання спроможностей дозволив зробити висновки про необхідність розробки та впровадження до практики ЗС України модульного оцінювання функціонування медичних підрозділів 3 використанням принципів багатокритеріальної оптимізації.

Мета. Розробити можливі підходи до кількісного оцінювання спроможностей медичних підрозділів $3 С$ України та їх функціональних модулів.

Матеріали та методи. Бібліосемантичний, системного аналізу та підходу, концептуального моделювання, медико-статистичний.

Результати. Мета медичного забезпечення збройних сил досягається виконанням сукупності завдань для вирішення яких існують медичні підрозділи, заклади та керівні медичні органи. Постає необхідність визначення таких завдань, які були б реальні для виконання в умовах впливу зовнішніх та внутрішніх факторів, та з іншої сторони - забезпечували необхідний рівень надання медичного забезпечення основних сил. Оскільки медичне забезпечення $\epsilon$ багатокомпонентною системою з безліччю критеріїв та показників, постає проблема в об'єктивному порівнянні рівня набутих медичними підрозділами спроможностей з необхідними. Практика країн, що запровадили на державному рівні оборонне планування на основі спроможностей, показує, що стандартизація модульної побудови медичних підрозділів збройних сил та оцінювання спроможностей за елементами системи DOTMLPF-I забезпечує високу готовність підрозділів, більш ефективну та гнучку роботу під час виконання покладених на них завдань. Якісне, обгрунтоване та стандартизоване оцінювання спроможностей дасть змогу виявляти ризики, мінімізувати суб'єктивне тлумачення вимог до спроможностей та наблизити функціональну, організаційну та ресурсну сумісність медичних підрозділів Сил оборони України та Північноатлантичного альянсу. Зазначене вище актуалізує необхідність розробки методології оцінювання спроможностей медичних підрозділів ЗС України наближеної до стандартів НАТО.

Висновки. Незважаючи на те, що у ЗС України вже багато років триває робота стосовно набуття взаємосумісності з державами-членами НАТО, розробки доктрини з оцінювання та методичних рекомендацій з оцінювання (сертифікації), дослідження питань оборонного планування на основі спроможностей та проблем оцінки спроможностей досліджена недостатньо. Робота з розробки методів оцінювання спроможностей медичних підрозділів триває і досі. В результаті системного аналізу виявлено значні відмінності в рівнях оцінювання спроможностей медичного забезпечення збройних сил, функціональній побудові медичних підрозділів та розбіжності в критеріях оцінювання спроможностей, що дозволяє запропонувати методичний підхід щодо оцінювання.

Ключові слова: модулі, оцінювання спроможностей, медичні підрозділи, збройні сили.

Вступ. Відповідно до Стратегічного оборонного бюлетеня України, метою проведення оборонної реформи в Україні $\epsilon$ набуття та підтримання силами оборони необхідного рівня бойової готовності і здатності до виконання завдань 3 оборони держави, підвищення рівня оперативної сумісності ЗС України та збройних сил держав НАТО. Одним із шляхів досягнення визначеної мети $\epsilon$ впровадження ефективної політики планування і управління ресурсами в секторі оборони з використанням євроатлантичних підходів оборонного планування на основі спроможностей. Оцінювання спроможностей медичних підрозділів військових частин $3 \mathrm{C}$ України і $\epsilon$ невід'ємною частиною оборонного планування на основі спроможностей та вимога вступу України в НАТО.

Аналіз нормативно-правових документів свідчить, що на теперішній час методика оцінювання спроможностей медичних підрозділів 3С України ще недосконала та потребує оптимізації в частині уточнення показників кількісного оцінювання спроможностей медичних підрозділів Збройних Сил України.

Запропоновано використовувати методи багатокритеріальної оптимізації для 
отримання кількісної оцінки спроможностей медичних підрозділів до виконання завдань.

Мета. Розробити можливі підходи до кількісного оцінювання спроможностей медичних підрозділів 3С України та їх функціональних модулів.

Матеріали та методи дослідження. Бібліосемантичний, системного аналізу та підходу, концептуального моделювання, медико-статистичний. У дослідженні зроблено контент-аналіз нормативно-правової бази України та спільноти НАТО 3 питань оборонного планування на основі спроможностей (ОПОС) та оцінювання спроможностей (ОС) медичних підрозділів. Разом з тим використовувалися літературні джерела за темою, матеріали зборів керівного складу Медичних сил та звітні матеріали за підсумками навчань підрозділів 3С України.

Результати дослідження та їх обговорення. Аналіз керівних документів та міжнародних угод зі стандартизації НАТО показав, що процедура оцінювання спроможностей $є$ одним з етапів у процесі оборонного планування на основі спроможностей та є умовою для ефективного планування розвитку військ, проте існуючі підходи до оцінювання спроможностей досить формалізовані. Оцінювання спроможностей медичних підрозділів військових частин в таких умовах $€$ актуальним питанням щодо розвитку оборонного планування сил оборони України та прогнозування імовірного розвитку бойових дій.

Існуючі підходи до оцінювання спроможностей регламентовані доктриною 3 оцінювання та методичними рекомендаціями 3 оцінювання (сертифікації) та низкою додаткових наказів, постанов які носять рекомендаційний характер. За ними під оцінкою розуміють порівняння необхідних спроможностей (оперативних, бойових, спеціальних) затверджених „Єдиним переліком спроможностей Міністерства оборони України, Збройних Сил України та інших складових сил оборони» (далі Каталог), для виконання завдань за кожним імовірним сценарієм розвитку кризових ситуацій та наявних спроможностей сил і засобів $[25,22$, $24,23,26,21,18,9,19]$.

Носієм спроможності $\epsilon$, як окрема одиниця (модуль, підрозділ, одиниця техніки, система тощо) так і сукупність сил і засобів, 3 очікуваним ефектом під час виконання завдання при заданих умовах та за встановлений час. Опис спроможностей у Каталозі здійснено згідно 3 додатком 1 до Рекомендацій з ОПОС в Міністерстві оборони (M0) України та 3С України, та містить вимоги до спроможностей $[27,18]$. Вимоги до спроможностей сформульовано відповідно до функцій, які покладаються на носія спроможності. Оскільки спроможності $\epsilon$ багатокритеріальними, ми пропонуємо поєднувати вимоги до них у функціональні модулі. Так, ще на початку 2010 року, відповідно до COMEDS Vision and Strategic Goals, однією зі стратегічних цілей медичної служби НАТО $є$ підвищення рівня взаємосумісності складових та більшої кооперації партнерів за рахунок багатонаціональності та стандартизації $[2,5]$. У цій статті автор пояснює необхідність багатонаціонального співробітництва та визначення стандартів роботи багатонаціональних медичних підрозділів для забезпечення мінімальних вимог до якості. Ця потреба привела до розробки AMedP-27, Керівництва НАТО з медичного оцінювання і оприлюдненню у 2010 році стандарту STANAG 2650. I впродовж наступних років цей принцип побудови та оцінювання дістав подальшого розвитку $[13,1]$.

Модульний підхід - це концептуальна ідея для підвищення ефективності та адаптивності медичного забезпечення. Він заснований на об'єднанні та обміні стандартизованими модулями спроможностей. Ці модулі можна переставляти, змінювати, комбінувати та замінити відповідно до потреб місії [6]. Так, відповідно до публікації Військового комітету MC 326/4 - Principles and Policies of Medical Support, для ефективного функціонування медичного забезпечення у сучасному середовищі, однією 3 цілей $\epsilon$ розробка модульних спроможностей [10]. У Спільній Доктрині з медичного забезпечення НАТО АJP4.10 Edition C Version 1 від 2019 року визначено модульний підхід у медичній підтримці багатонаціональних контингентів [6]. Отже відповідно до стандартів та публікацій НАТО $[7,8,9,6,10]$ виділяють такі модулі для медичних підрозділів як наведено у таблиці 1.

Для кожного носія визначаються набір модулів за функціональними напрямками у відповідності до покладених завдань. 
Модулі медичних підрозділів НАТО

\begin{tabular}{|c|c|c|c|c|}
\hline \multicolumn{5}{|c|}{ Модулі } \\
\hline \multicolumn{5}{|c|}{ Основні } \\
\hline Початкова хірургія & \multicolumn{2}{|l|}{ Стаціонар } & \multicolumn{2}{|c|}{ Невідкладна допомога } \\
\hline Діагностичний модуль & \multicolumn{2}{|c|}{ Післяопераційний догляд } & \multicolumn{2}{|c|}{ Медичне постачання } \\
\hline \multicolumn{5}{|c|}{ Командування, контроль, зв'язок та комунікації } \\
\hline \multicolumn{5}{|c|}{ Підсилення } \\
\hline Діагностика & KT & \multicolumn{2}{|c|}{ Хірургія } & Стерилізаційна \\
\hline BAPIT & Палати & \multicolumn{2}{|c|}{ Ізолятор } & Лабораторія \\
\hline Аптека & Управління & \multicolumn{2}{|c|}{ Первинна мед. } & Стоматологія \\
\hline \multicolumn{5}{|c|}{ Психологічна підтримка } \\
\hline \multicolumn{5}{|c|}{ Додаткові } \\
\hline $\begin{array}{l}\text { Лікування } \\
\text { ЗМУ }\end{array}$ & Спеціальна хірургія & \multicolumn{2}{|c|}{ Кисневе забезпечення } & $\begin{array}{l}\text { Профілактична } \\
\text { медицина }\end{array}$ \\
\hline Гіпербаричний блок & Телемедицина & \multicolumn{2}{|c|}{ Автошвидкі } & MPT \\
\hline Кріобанк крові & Ветеринарія & \multicolumn{2}{|c|}{ Морг } & Фізіотерапія \\
\hline
\end{tabular}

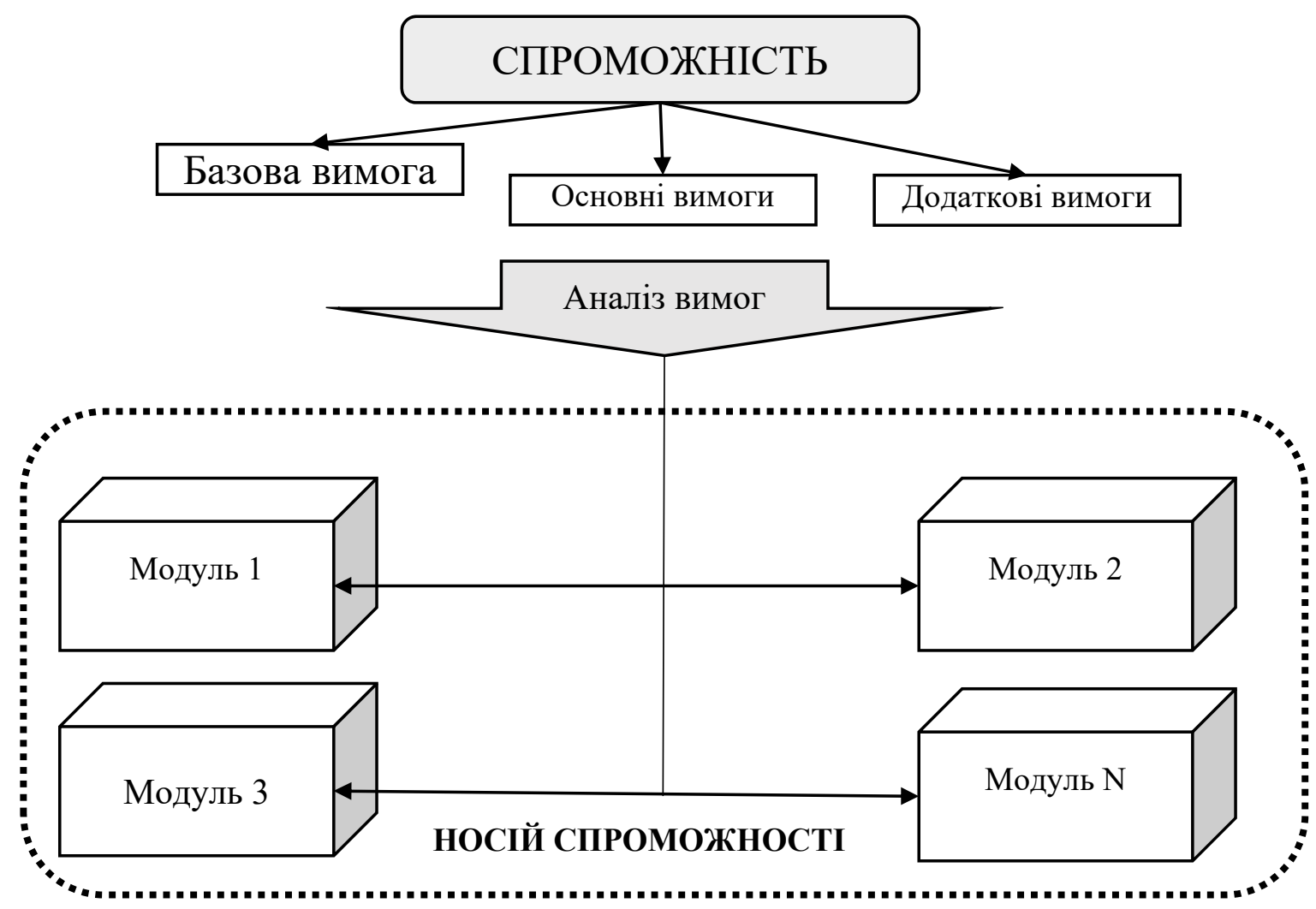

Рисунок 1. Модульна структура носія спроможності.

Під час проведення оцінювання спроможностей експертами робочої групи 3 OC, виходячи з необхідних ефектів відносять вимоги до модулів, які містять в собі їх сукупність подібну за функціоналом (рис. 1). Далі для кожної вимоги визначаються критерії та необхідні показники або оптимальний їх діапазон [27]. На теперішній час спроможності в 3С України оцінюють за такими основними критеріями: «персонал», «запаси», «озброєння» та «навченість» [19], проте ми пропонуємо розділити критерії у відповідності до компонентів розвитку спроможностей DOTMLPF-I HATO.

Кожен компонент спроможності може мати свої, притаманні лише йому, властивості та критерії, а показники мають бути як кількісними так і якісними. 
Кількісні показники компонентів отримують розрахунками (напр. санітарні втрати) або вимірюванням (ліжко-місця військового мобільного госпіталя). Якісні показники вираховують відповідно до вимог затверджених методів їх визначення (вмотивованість особового складу медичного підрозділу до виконання завдань за призначенням; лідерські якості командира підрозділу) у абсолютних показниках або експертним методом із використанням бальної оцінки. Проте за різними видами показників все ще неможливо оцінювати спроможність медичного підрозділу. Для цього потрібен спосіб об'єктивно порівняти різні критерії вимог спроможностей. Низка авторів [15, 16] розглядає можливість оцінювання спроможностей за принципами кваліметрії - кількісної оцінки процесів за допомогою шкали балів. Один 3 основних принципів цього метода полягає у зведенні різних показників, які характеризують окремі критерії об'єкта до узагальненого показника.

Пропонуємо нормування різних показників до інтегрального показника, що надає змогу зіставити властивості спроможностей, які мають різні одиниці виміру (для визначення та розвитку оптимального варіанту). Це також дозволить отримувати кількісну оцінку спроможності медичного підрозділу та визначити ступінь наближення спроможності до необхідного рівня.

В процесі порівняння показників критеріїв спроможностей медичних підрозділів 3С України їх необхідно привести до безрозмірного виду - інтегрального показника (SHi) (1.1-1.3). Якщо відоме необхідне значення показника (вимоги за Каталогом або технічне завдання 3 оцінювання), то:

$$
\text { Sнi }=\text { Si } / \text { Si необх. }
$$

де $S H i$ - інтегральний показник властивості; $S i$ - абсолютний показник властивості; Si необх необхідний показник властивості (Si необх $\rightarrow$ max); $i=1,2, \ldots n$; діапазон вимірювань $0 \leq$ SHi $\leq 1$.

Якщо задано діапазон в якому змінюється показник від $S^{\min }$ до $S^{\max }$, то

$$
\begin{aligned}
& S н i=S i /\left(S i^{\text {max }}-S i^{\text {min }}\right), \\
& \text { або } \\
& S \text { Hi }=\left(S i-S i^{\text {min }}\right) /\left(S i^{\text {max }}-S i^{\text {min }}\right)
\end{aligned}
$$

де $S H i$ - інтегральний показник властивості; $S i$ - абсолютний показник властивості; $S^{\min }$ до $S^{\text {max }}$ - мінімальне та максимальне значення показника властивості, відповідно; $i=1,2, \ldots n$.
При комплексному оцінюванні потрібно враховувати, що для більшості критеріїв існують такі показники, низьке значення яких не може бути компенсовано високим значенням інших показників. Наприклад, низька укомплектованість персоналом не може бути компенсована високим рівнем кваліфікації. Тому для запобігання такої ситуації, пропонуємо застосовувати середній геометричний показник, який попередить «перекриття» одних показників іншими (2). Якщо якийнебудь показник має значення, що не відповідає нормі стандарту або оцінюється балом 0 , то критерій визнається непридатним незалежно від високого значення інших показників.

Отже цільова функція для оцінювання модулів може мати такий вигляд:

$$
M_{\text {мn }}=\sqrt[n]{\prod_{i=1}^{n} S_{\mathrm{Hi}}}
$$

де $M_{\text {мn }}$ - оцінка функціонального модуля спроможності медичного підрозділу; $S H i$ - інтегральний показник $i$-го критерію; n кількість показників.

На вимоги затвердженої інструкції критеріями за якими оцінюються спроможності $\epsilon$ «персонал», «озброєння», «запаси» та «навченість».

Але на нашу думку цих критеріїв недостатньо і для наближення до DOTMLPF-I системи пропонуємо розширити елементами «Доктрина», «Організація», «Лідерство», «Сумісність» як окремі, і віднести до вищевказаних критеріїв елементи «Training» до «Навченість», «Materiel» до «Запаси», «Personal» до «Персоналу» та «Facilities» до «Озброєння», як тотожні. Загалом основними критеріями оцінювання спроможностей медичних підрозділів 3С України будуть «Доктрина», «Організація», «Лідерство», «Персонал», «Озброєння», «Запаси», «Навченість».

Тоді цільова функція оцінки модуля відповідно до (2) має вигляд:

$$
M_{\text {мn }}=\sqrt[8]{(Д * 0 р г * Л * \Pi * \text { Озб } * 3 * \mathrm{H} * \mathrm{C})},
$$

де $M_{\text {мn }}$ - оцінка функціонального модуля спроможності медичного підрозділу; Д, Орг, Л, П, Озб, 3, Н, С - оцінки модулю медичного підрозділу за відповідні елементи системи DOTMLPF-I.

Також, необхідно розуміти, що модульність носія спроможності (медичного підрозділу) універсальна і за різних сценаріїв застосування не змінна. Проте відповідно до зміни умов застосування може змінюватися вплив на кінцевий результат. Тобто доцільно 
застосувати вагові коефіцієнти до модулів (для різних сценаріїв застосування підрозділів ЗС України визначається свій коефіцієнт).

Отже, як ціле, оцінка спроможності $\epsilon$ сукупністю оцінок модулів спроможності виражена через середній зважений геометричний показник (3).

$$
C_{\text {Mn }}=\left(\prod_{i=1}^{n} M i^{k i}\right)^{1 / \sum_{i=1}^{n} k i}
$$

де $C_{м n}$ - оцінка спроможності медичного підрозділу; $\mathrm{M}_{i}$ - оцінка $i$-го модулю спроможності; $k_{i}$ - ваговий коефіцієнт $i$-го модулю спроможності; n - кількість модулів.

Результати кількісного розрахунку спроможності можна перевести у загальноприйняту шкалу оцінок спроможностей НАTO за допомогою вербально-числової шкали Харрінгтона $[3,15$, $16,7,17,12,14,11]$. Шкала Харрінгтона - це інтервальна дискретна вербально-числова шкала, що складається 3 п'яти інтервалів одиничного відрізку, що характеризує ступінь наближення до бажаного значення: дуже висока $(0,8-1,0)$; висока $(0,64-0,8)$; середня $(0,37-0,63)$; низька $(0,2-0,36)$; дуже низька $(0$
- 0,2). Наведені числові значення отримані на основі статистичного аналізу та обробки великої кількості експертних даних. Вона переводить якісні оцінки в кількісні в інтервалі від 0 до 1 на основі статистичної обробки психологічних особливостей людини (психометрична шкала Лікерта) [20, 4]. Завдяки цьому шкала Харрінгтона має універсальне застосування і може використовуватися у відповідних модифікаціях. Оскільки «низькі» та «дуже низькі» значення не відповідають потребам 3С України, тому ці значення об'єднаємо в одну категорію - «не спроможний». «Середній» рівень 3 показниками від 0,37 до 0,64 також не задовольняє потребам 3C України. Прийнятними для використання в оцінювання спроможностей медичних підрозділів 3С України є високий та дуже високий рівні, але ураховуючи те що за деякими критеріями оцінювання нижчий прийнятний рівень показників визначено на рівні $0,7 *$ (або 70\%), то пропонується використовувати наступні інтервали (табл. 2.):

Таблиия 2

Вербально-числова оцінка спроможностей медичних підрозділів

\begin{tabular}{|l|l|r|c|}
\hline № & \multicolumn{1}{|c|}{$\begin{array}{l}\text { Оцінка НАТО (вербальна оцінка за } \\
\text { Лікертом) }\end{array}$} & Оцінка ЗС України & Кількісне значення \\
\hline 1 & $(-)$ & Надлишкові спроможності & $0,8-1,0$ \\
\hline 2 & $\begin{array}{l}\text { Повністю функціонуючий (дуже } \\
\text { висока) }\end{array}$ & Спроможний & $0,7^{*}-0,79$ \\
\hline 3 & $\begin{array}{l}\text { Функціонуючий, присутні незначні } \\
\text { ризики (висока) }\end{array}$ & Обмежено спроможний & $0,37-0,63\left(0,69^{*}\right)$ \\
\hline 4 & $\begin{array}{l}\text { Функціонуючий 3 ризиками } \\
\text { (середня) }\end{array}$ & Не спроможний & $<0,36$ \\
\hline 5 & $\begin{array}{l}\text { (низька + дуже низька) } \\
\text { Примітка: * нижчий прийнятний рівень показників визначено на рівні } 0,7\end{array}$ \\
\hline
\end{tabular}

Наведені у таблиці числові значення отримані на основі статистичного аналізу достатньої кількості даних, завдяки чому шкала Харрінгтона має універсальне застосування і може використовуватися у відповідних модифікаціях.

\section{Висновки}

\section{1. Для} оцінювання підрозділів проведення спроможностей об'єктивного принципи багатокритеріальної оптимізації. Приведення показників спроможностей 3 різними одиницями вимірювання до інтегрального показника дає змогу порівняти та оцінити спроможності, що мають різні одиниці виміру.
Подальші дослідження будуть спрямовані на оптимізацію методики модульного кількісного оцінювання спроможностей медичних підрозділів 3С України.

2. Модульний підхід до побудови системи медичного забезпечення сприяє підвищенню функціональних спроможностей медичних підрозділів та військово-медичних закладів на всіх рівнях медичного забезпечення, забезпечить сумісність медичної служби 3С України та інших складових Сил оборони України між собою, а також 3 медичними службами збройних сил держав - членів НАТО. Тому оцінювання спроможностей медичних підрозділів 3С України за модульним 
принципом $\epsilon$ невід'ємною вимогою ефективного ОПОС та досягнення сумісності 3 багатонаціональними підрозділами НАТО та $\mathrm{OOH}$.

3. Запропоноване удосконалення методики модульної оцінки спроможностей

\section{Література}

1. Balkan medical task force. Military-Medicine : веб-сайт. URL: https://militarymedicine.com/article/3713-balkan-medical-taskforce.html (дата звернення 04.04.2021).

2. COMEDS Vision and Strategic goals: NATO Strategic concept 10.11.2015. URL: https://www.coemed.org/files/COMEDS/COMEDSCH AIRL20150022-

COMEDS\%20Vision\%20and\%20Strategic\%20goals.pd $\mathrm{f}$ (дата звернення: 13.10.2019).

3. Harington E. C. The desirability function. Industrial Quality Control. 1965. 21. p. 494-498.

4. Likert R. A technique for the measurement of attitudes. Archives of Psychology. 1932. Vol. 22. p. 5-55.

5. MILMED COE vision and strategic guidance 2017 - 2021: NATO Strategic plan 07.07.2017. URL: https://www.coemed.org/files/static texts/strategic guidance update\%202017-07-07\%20DD.pdf (дата звернення: 13.10.2019)

6. NATO STANAG 2228. AJP-4.10(C). Allied joint doctrine for medical support. 2019.124 p.

7. NATO STANAG 2560. AMedP-1.6 Medical Evaluation Manual. Edition A Version 2. 2018. 134 p.

8. NATO STANAG 2560. AMedP-1.7 Capability Matrix. January. 2016. 22 p.

9. NATO STANAG 2560. AMedP-1.8 Skills Matrix. January. 2016. $88 \mathrm{p}$.

10. NATO MC 326/4. Principles and policies of medical support. 2018. 23 p.

11. Nikulin A., Klimova I., Mrackova E. Practical Approach to Assessment of Effectiveness and Efficiency of Management Systems for Occupational Safety. Preprints 2020.2 URL: https://www.preprints.org/manuscript/202008.0152 Lv1 (дата звернення: 11.03.2021)

12. Quirante T., Sebastian P., Ledoux Y. A trade-off function to tackle robust design problems in engineering. Journal of Engineering Design. 2012. Vol 24. P. $1-18$

13. Recent Developments in Medical Evaluation. Military-Medicine : веб-сайт. URL: https://militarymedicine.com/article/3655-recent-developments-inmedical-evaluation.html (дата звернення 04.04.2021).

14. Voitenko L. V., Kopilevych V. A. Optimization of the analytical reagent $(\mathrm{Ar}) \mathrm{Co}_{3}\left(\mathrm{PO}_{4}\right)_{2} 8 \mathrm{H}_{2} \mathrm{O}$ synthesis conditions using the Harrington's desirability function. Біоресурси і природокористування. 2014. Т. 6. № 3-4. C. 27-35

15. Дідіченко В. П. Методичний підхід до кількісного оцінювання достатності спроможностей організаційної одиниці (сукупності медичних підрозділів 3С України дозволяє кількісно оцінювати їх та дає змогу визначити ступінь наближення спроможності до необхідного рівня.

сил і засобів) складу військ (сил). Системи озброєння і військова техніка. 2019. № 1. С. 85-89.

16. Дідіченко В.П., Соломицький O.I. Методичний підхід до кількісного оцінювання показників спроможностей з'єднань (частин) протиповітряної оборони. Наука $i$ техніка Повітряних Сил Збройних Сил Украӥни. 2019. № 2(35). С. 27-32.

17. Доктрина 3 організації оцінювання (сертифікації) в Збройних Силах України: затв. начальником Генерального штабу від 4.10.2020 p. ВКП 7-00(03).02.33 с.

18. Єдиний перелік (каталог) спроможностей Міністерства Оборони України, Збройних Сил України та інших складових Сил оборони: затв. Міністром оборони України від 09.12.2019 р. 618 с.

19. Методичні рекомендації 3 оцінювання (сертифікації) органів військового управління, військових частин (підрозділів) Збройних Сил України щодо набуття визначених спроможностей: затв. начальником Генерального штабу від 4.10.2020 р. ВКДП 7-00(03).01. 79 с.

20. Новак В. О., Мостенська Т. Л., Ільєнко О. В. Організаційна поведінка: Підручник.: Київ, 2013. 498 c.

21. Про затвердження Порядку проведення оборонного огляду Міністерством оборони : Постанова Кабінету Міністрів України від 31.10.2018 p № 941. URL: http://lsearch.ligazakon.ua/ldoc2 (дата звернення: 05.05.2021).

22. Про національну безпеку України : Закон України від 21 черв. 2018 р. № 2469-VIII. URL: https://zakon.rada.gov.ua/laws/show/2469-19\#Text (дата звернення: 05.05.2021).

23. Про рішення Ради національної безпеки i оборони України від 20 травня 2016 року «Про Стратегічний оборонний бюлетень України» : Указ Президента України від 6 черв. 2016 р № 240/2016. URL:

https://zakon.rada.gov.ua/laws/show/240/2016\#Te xt (дата звернення: 04.04.2021).

24. Про рішення Ради національної безпеки і оборони України від 25 березня 2021 року «Про Стратегію воєнної безпеки України» : Указ Президента України від 25 бер. 2021 р № 121/2021. URL:

https://zakon.rada.gov.ua/laws/show/121/2021\#n2 (дата звернення: 04.04.2021).

25. Рекомендації з оборонного планування на основі спроможностей в Міністерстві оборони України та Збройних Силах України: затв. Міністром оборони України від 12.06.2017. 52 с. 
26. Рекомендації 3 порядку організації проведення оцінювання спроможностей у Збройних Силах України: затв. Міністром оборони України від 10.12.2017. 23 с.

27. Сурков 0.0. Підхід до визначення сутності понять «спроможність», «можливість», «здатність» сил оборони для вдосконалення основ стратегічного планування. Збірник наукових праць Центру воєнно-стратегічних досліджень Національного університету оборони України імені Івана Черняховського. 2017. №1(59). С. 35-40.

\section{References}

1. Balkan medical task force. Military-Medicine. (2019). Retrieved from: https://militarymedicine.com/article/3713-balkan-medical-taskforce.html.

2. COMEDS Vision and Strategic goals: NATO Strategic concept. (2015). Retrieved from https://www.coemed.org/files/COMEDS/COMEDSCH AIRL20150022-

COMEDS\%20Vision\%20and\%20Strategic\%20goals.pd f.

3. Harington, E. C. (1965). The desirability function. Industrial Quality Control, 21, 494-498.

4. Likert, R. (1932). A technique for the measurement of attitudes. Archives of Psychology, Vol. 22, 5-55.

5. MILMED COE vision and strategic guidance 2017 - 2021: NATO Strategic plan (2017). Retrieved from

https://www.coemed.org/files/static_texts/strategic guidance_update\%202017-07-07\%20DD.pdf

6. AJP-4.10(S). Allied joint doctrine for medical support. (2019). NATO STANAG 2228.

7. AMedP-1.6. Medical Evaluation Manual. (2018). NATO STANAG 2560. Edition A Version 2.

8. AMedP-1.7. Capability Matrix. (2016). NATO STANAG 2560.

9. AMedP-1.8. Skills Matrix. (2016). NATO STANAG 2560.

10. NATO MS 326/4. Principles and policies of medical support. (2018).

11. Nikulin, A., Klimova, I., \& Mrackova, E. (2020) Practical Approach to Assessment of Effectiveness and Efficiency of Management Systems for Occupational Safety. Preprints Retrieved from https://www.preprints.org/manuscript/202008.0152 /v1

12. Quirante, T., Sebastian, P., \& Ledoux, Y. (2012). A trade-off function to tackle robust design problems in engineering. Journal of Engineering Design, 24, 1-18

13. Recent Developments in Medical Evaluation. Military-Medicine. (2019). Retrieved from https://military-medicine.com/article/3655-recentdevelopments-in-medical-evaluation.html

14. Voitenko, L. V., \& Kopilevych, V. A. (2014). Optimization of the analytical reagent (Ar) Co3(P04)2 8H2O synthesis conditions using the Harringtons desirability function. Bioresursy

pryrodokorystuvannia, 3-4, 27-35.

15. Didichenko, V.P. (2019). Metodychnyi pidkhid do kilkisnoho otsiniuvannia dostatnosti spromozhnostei orhanizatsiinoi odynytsi (sukupnosti syl i zasobiv) skladu viisk (syl) [Methodical approach to quantitative assessment of the adequacy of the capabilities of the organizational unit (set of forces and means) of the troops (forces)]. Systemy ozbroiennia $i$ viiskova tekhnika,. 1, 85-89 [in Ukrainian].

16. Didichenko, V.P., \& Solomytskyi, O.I. (2019). Metodychnyi pidkhid do kilkisnoho otsiniuvannia pokaznykiv spromozhnostei ziednan (chastyn) protypovitrianoi oborony [Methodical approach to quantitative assessment of air defense units capabilities]. Nauka $i$ tekhnika Povitrianykh Syl Zbroinykh Syl Ukrainy, 2(35), 27-32 [in Ukrainian].

17. Doktryna $\mathrm{z}$ orhanizatsii otsiniuvannia (sertyfikatsii) v Zbroinykh Sylakh Ukrainy [Doctrine on the organization of assessment (certification) in the Armed Forces of Ukraine] Activity from October 4 2020, p. 33 [in Ukrainian].

18. Yedynyi perelik (kataloh) spromozhnostei Ministerstva Oborony Ukrainy, Zbroinykh Syl Ukrainy ta inshykh skladovykh Syl oborony [Unified list (catalog) of capabilities of the Ministry of Defense of Ukraine, the Armed Forces of Ukraine and other components of the Defense Forces] Activity from December 09 2019, p. 618 [in Ukrainian].

19. Metodychni rekomendatsii $\mathrm{z}$ otsiniuvannia (sertyfikatsii) orhaniv viiskovoho upravlinnia, viiskovykh chastyn (pidrozdiliv) Zbroinykh Syl Ukrainy shchodo nabuttia vyznachenykh spromozhnostei [Methodical recommendations on assessment (certification) of military administration bodies, military units (subdivisions) of the Armed Forces of Ukraine regarding the acquisition of certain capabilities] Activity from October 42020 , p. 79 [in Ukrainian].

20. Novak, V. O., Mostenska, T. L., \& Ilienko, O. V. (2013). Orhanizatsiina povedinka [Organizational behavior]. Kyiv [in Ukrainian].

21. Pro zatverdzhennia Poriadku provedennia oboronnoho ohliadu Ministerstvom oborony [On approval of the Procedure for conducting a defense inspection by the Ministry of Defense]: Postanova Kabinetu Ministriv Ukrainy vid 31.10.2018 r № 941. Retrieved from http://lsearch.ligazakon.ua/ldoc2 [in Ukrainian]

22. Law of Ukraine On the national security of Ukraine Activity from June 21 2018, № 2469-VIII. Retrieved from https://zakon.rada.gov.ua/laws/show/2469-19\#Text [in Ukrainian]

23. Law of Ukraine About the Strategic Defense Bulletin of Ukraine Activity from May 20 2016, № $240 / 2016$. Retrieved from 
https://zakon.rada.gov.ua/laws/show/240/2016\#Te xt [in Ukrainian]

24. Law of Ukraine On the Military Security Strategy of Ukraine Activity from March 25 2021, № 121/2021. Retrieved from https://zakon.rada.gov.ua/laws/show/121/2021\#n2 [in Ukrainian]

25. Rekomendatsii z oboronnoho planuvannia na osnovi spromozhnostei $v$ Ministerstvi oborony Ukrainy ta Zbroinykh Sylakh Ukrainy [Recommendations on capability-based defense planning in the Ministry of Defense of Ukraine and the Armed Forces of Ukraine] Activity from June 12 2017, p. 52 [in Ukrainian].

26. Rekomendatsii $z$ poriadku orhanizatsii provedennia otsiniuvannia spromozhnostei u Zbroinykh
Sylakh Ukrainy [Recommendations on the procedure for organizing capability assessment in the Armed Forces of Ukraine] Activity from December 10 2017, p. 23 [in Ukrainian].

27. Surkov, 0.0. (2017). Pidkhid do vyznachennia sutnosti poniat «spromozhnist», «mozhlyvist», «zdatnist» syl oborony dlia vdoskonalennia osnov stratehichnoho planuvannia [Approach to defining the essence of the concepts «capacity», «opportunity», «ability» of the defense forces to improve the basics of strategic planning]. Zbirnyk naukovykh prats Tsentru voienno-stratehichnykh doslidzhen Natsionalnoho universytetu oborony Ukrainy imeni Ivana Cherniakhovskoho, 1(59), 35-40 [in Ukrainian].

\title{
МЕТОДИЧЕСКИЙ ПОДХОД К КОЛИЧЕСТВЕННОМУ ОЦЕНИВАНИЮ ВОЗМОЖНОСТЕЙ МЕДИЦИНСКИХ ПОДРАЗДЕЛЕНИЙ ВООРУЖЕННЫХ СИЛ УКРАИНЫ
}

\author{
E.A. Зуй
}

Украинская военно-медицинская академия, г. Киев, Украина

Введение. В статье предложен методический подход к модульному количественному оцениванию возможностей медицинских подразделений Вооруженных Сил Украины, в основу которого положен модульный подход $\kappa$ построению $и$ оценке медицинских подразделений, применяемый в Североатлантическом Альянсе. Анализ утвержденных методов оценки способностей позволил сделать выводы о необходимости разработки и внедрения в практику ВС Украины модульного оценивания функционирования медицинских подразделений с использованием принципов многокритериальной оптимизации.

Цель. Анализ возможного подходов к количественной оценки возможностей медицинских подразделений ВС Украины и их функциональных модулей.

Материалы и методы. Библиографический, системного анализа и подхода, концептуального моделирования, медико-статистический.

Результаты. Цель медицинского обеспечения вооруженных сил достигается выполнением совокупности задач, для решения которых существуют медицинские подразделения, учреждения и руководящие медицинские органы. Возникает необходимость определения таких задач, которые были бы реальны для выполнения в условиях воздействия внешних и внутренних факторов, и с другой стороны обеспечивали необходимый уровень медицинской поддержки основных сил. Поскольку медицинское обеспечение является многокомпонентной системой со множеством критериев и показателей, возникает проблема в объективном сравнении уровня приобретенных медицинскими подразделениями возможностей с необходимыми. Практика стран ввели на государственном уровне оборонное планирование на основе возможностей, показывает, что стандартизация модульного построения медицинских подразделений вооруженных сил и оценки возможностей по элементам системы DOTMLPF-I обеспечивает высокую готовность подразделений, более эффективную и гибкую работу при выполнении возложенных на них задач. Качественное, обоснованное и стандартизированное оценки возможностей позволит выявлять риски, минимизировать субъективное толкование требований к возможностям и приблизить функциональную, организационную и ресурсную совместимость медицинских подразделений Сил обороны Украины и Североатлантического альянса. Указанное выше актуализирует необходимость разработки методологии оценки возможностей медицинских подразделений ВС Украины приближенной к стандартам HATO.

Выводы. Несмотря на то, что в ВС Украины уже много лет идет работа по достижению совместимости с государствами-членами НАТО, разработке доктрины по оцениванию и методических рекомендаций по оцениванию (сертификации), исследование вопросов оборонного планирования на основе возможностей и проблем оценивания возможностей исследована недостаточно. Работа по разработке методов оценивания возможностей медицинских подразделений продолжается до сих пор. В результате системного анализа выявлены значительные различия в уровнях оценивания возможностей медицинского обеспечения вооруженных сил, функциональной построении медицинских подразделений и разногласия в критериях оценивания возможностей, что позволяет предложить методический подход к оцениванию.

Ключевые слова: модули, оценивание возможностей, медицинские подразделения, вооруженные силы. 


\title{
METHODICAL APPROACH TO QUANTITATIVE EVALUATION OF MEDICAL UNITS' CAPABILITIES OF THE ARMED FORCES OF UKRAINE
}

\author{
Y.O. Zui \\ Ukrainian Military Medical Academy, Kyiv, Ukraine
}

Introduction. The article proposes a methodical approach to the modular quantitative evaluation of the capabilities of medical units of the Armed Forces of Ukraine, which is based on the modular approach to the construction and evaluation of medical units used in the North Atlantic Alliance. The analysis of the approved methods of capability evaluation allowed to draw conclusions about the need to develop and implement in the practice of the Armed Forces of Ukraine modular evaluation of the functioning of medical units using the principles of multicriterial optimization.

The purpose: to develop possible approaches to quantitative assessment of the capabilities of medical units of the Armed Forces of Ukraine and their functional modules. statistical.

Materials and methods. Bibliographic, system analysis, system approach, conceptual modeling, medical and

Results. The purpose of medical support of the armed forces is achieved by performing a set of tasks for the solution of which there are medical units, institutions and governing medical bodies. There is a need to identify such tasks that would be realistic to perform under the influence of external and internal factors, and on the other hand provide the necessary level of medical care for the main forces. Because health care is a multi-component system with many criteria and indicators, there is a problem in objectively comparing the level of capabilities acquired by medical units with the required ones. The practice of countries that have implemented capability-based defense planning at the state level shows that the standardization of modular construction of medical units of the armed forces and capability evaluation by elements of the DOTMLPF-I system provides high readiness of units, more efficient and flexible work. Qualitative, justified and standardized capability evaluation will allow to identify risks, minimize the subjective interpretation of capability requirements and bring closer the functional, organizational and resource compatibility of medical units of the Defense Forces of Ukraine and the North Atlantic Alliance. The above highlights the need to develop a methodology for evaluating the capabilities of medical units of the Armed Forces of Ukraine close to NATO standards.

Conclusions. Despite the fact that the Armed Forces of Ukraine have been working for many years on interoperability with NATO member states, development of evaluation doctrine and evaluation (certification) guidelines, research on capability-based defense planning and capability evaluation issues has been insufficiently studied. Work on the development of methods for evaluating the capabilities of medical units continues to this day. As a result of the system analysis, significant differences in the levels of evaluation of medical capabilities of the armed forces, functional construction of medical units and differences in the criteria for evaluating capabilities, which allows to propose a methodological approach to evaluation.

Key words: modules, capability evaluation, medical units, Armed Forces.

Відомості про автора:

Зуй Є.0. - капітан медичної служби, ад’юнкт науково-організаційного відділення Української військово-медичної академії, м.Київ. E-mail: mesterolon@gmail.com https://orcid.org/0000-0002-0546-5873

Сведения об авторе:

Зуй E.A. - капитан медицинской службы, адъюнкт научно-организационного отделения Украинской военно-медицинской академии, г. Киев

Information about author:

Zui Y.O.- capt. MS, Graduate Student Of The Scientific And Organizational Department Of The Ukrainian Military Medical Academy. https://orcid.org/0000-0002-0546-5873, Kyiv, E-mail: mesterolon@gmail.com

Адреса для листування: вул. Московська, 45/1, буд. 33, м. Київ 01015 